\title{
Skinfold Sum: Reference Values for Top Athletes
}

\author{
Sumatorio de Pliegues Subcutáneos: Valores de Referencia para Atletas de Élite
}

\author{
"Raul Garrido-Chamorro; ;* José Enrique Sirvent-Belando; *** Marta González-Lorenzo; \\ ${ }^{* * * * *}$ Cristina Blasco-Lafarga \& ${ }^{* * * * *}$ Enrique Roche
}

GARRIDO-CHAMORRO, R.; SIRVENT-BELANDO, J. E.; GONZÁLEZ-LORENZO, M.; BLASCO-LAFARGA, C. \& ROCHE, E. Skinfold sum: reference values for top athletes. Int. J. Morphol., 30(3):803-809, 2012.

SUMMARY: Skinfold determinations from different body parts are occasionally used in prediction equations to calculate fatness. This is a critical parameter that conditions optimal sport performance. Reference values of skinfolds in top athletes do not exist. Therefore, the main objective of this study is to present skinfold reference values from a large population of athletes. Triceps, subscapu lar, suprailiac, abdominal, thigh and medial calf skinfolds were measured according to ISAK (International Society for Advancement of Kinanthropometry) norms in 2500 athletes. Six skinfold sums as well as partial sums from different body segments (upper, trunk and lower) were applied. Data show that the highest skinfold values were observed for thigh calf and abdominal, being the subscapular the lowest. Women presented higher skinfold values than men. Concerning partial sums, trunk and lower body segments presented the highest scores. Subjects practicing hockey, handball, indoor soccer, rowing, scuba diving and table tennis displayed the highest fat percents. In conclusion, fatty mass calculation in athletes should consider the six skinfold sum. In addition, body fat tends to be localized in the trunk and lower body segments in athletes and varies according to gender and sport discipline.

KEYWORDS: Anthropometry; Body fat; Skinfolds; Body segments; Sports.

\section{INTRODUCTION}

Anthropometry is a discipline that provides information about body composition. Therefore, it can be used to design training and nutritional strategies for the correct preparation of the sports season for elite athletes. To this end, anthropometry provides data about major body compartments, such as fat, muscle, bone and viscera that are instrumental in sport performance. This can be achieved using prediction equations that are widely used and crossvalidated by the International Society for Advancement of Kinanthropometry (ISAK) for Caucasian-White populations (Marfell-Jones et al., 2006). Compared to other disciplines, anthropometry uses non-invasive, affordable and portable devices to determine skinfolds, weight, height and body circumferences and diameters. These devices are simple and easy to use, allowing rapid determinations and thus can be performed in large populations. Nevertheless, anthropometric measurements require trained personnel, standardization of the measurement, as well as, in some instances, the appropriate calibration of the instruments.
Currently, training and nutritional planning for athletes generally take in account body fat content, since high values of this parameter have a negative influence on optimal sport performance. To this end, adiposity determination of the athletes by anthropometry is instrumental for trainers and medical staff. One such case is the body mass index (BMI), calculated by the ratio of weight (in $\mathrm{kg}$ ) and the height value squared (in meters) $\left(\mathrm{kg} / \mathrm{m}^{2}\right)$. BMI has been considered as an indirect estimation of adiposity in epidemiologic studies. In Caucasians, a BMI value between 20 and $24.9 \mathrm{~kg} / \mathrm{m}^{2}$ is considered normal, $25-29.9 \mathrm{~kg} / \mathrm{m}^{2}$ is overweight and $30-35 \mathrm{~kg} / \mathrm{m}^{2}$ is obese (WHO Expert Consultation, 2004; Kagawa et al., 2006; Deurenberg et al., 1989). Therefore, it can be assumed that BMI is well correlated with the percentage of body fat (Malina, 2007) and for this reason it is a predictive parameter for several pathological situations, such as obesity and type 2 diabetes. However, BMI does not provide any information concerning the distribution of fat in the body, which could be a more

* Emergency Service, General Hospital of Alicante, Alicante, Spain.

** Department of Analytical Chemistry, Nutrition and Bromatology, University of Alicante, Alicante, Spain.

*** Intensive Care Unit, General Hospital of Alicante, Alicante, Spain.

**** Department of Physical Education and Sport, University of Valencia, Valencia, Spain.

${ }^{* * * * * *}$ Department of Applied Biology-Nutrition, University Miguel Hernandez of Elche, Alicante, Spain.

Funding: This work was supported by a grant from the Ministry of Science and Innovation (Spain) DEP-2005-00238-C04-02/EQUI to E Roche. 
practical question in sports. Furthermore, increments in muscle mass, typical in sport performance, have a direct influence in BMI values (Manila).

Alternatively, skinfold sum also provides an index to determine adiposity. For example, subcutaneous fat reflects the amount of fat present in the adipose tissue. In fact, 40$60 \%$ of body fat is in the subcutaneous region (Wang et al., 2000). On the other hand, particular skinfold determinations provide information concerning local fat depots and fat distribution in the body. Skinfold values can be easily and directly obtained using calipers. The information provided can be quickly interpreted, allowing the comparison between different groups. However, reference values of skinfolds in top athletes do not exist and the obtained values cannot be compared and validated in relation to other populations. Therefore, the main objective of this study is to provide skinfold reference values from a large population of Caucasian elite athletes that can be useful for trainers to design exercise and nutritional strategies in sports.

\section{MATERIAL AND METHOD}

The population studied (Caucasian-White) consisted in 2500 competitive-level athletes ( 729 women and $1771 \mathrm{men}$ ) which are officially registered in the records of the Generalitat Valenciana, published every year. The study was conducted during the 2000-2004 period. The last official recorded publication was DOGV 4744 in May $3^{\text {rd }} 2004$. The study was ethically conducted as according to regional laws (DOGV 4766 in June $6^{\text {th }}, 2004$ ) as well as to the ethical standards described in the 1964 Declaration of Helsinki. All subjects were informed of the study before giving their written consent. Athlete selection to be included in official records is performed as follows. Athletes are registered in the corresponding Secretariat of the Regional Sport Council. Each athlete receives a score according to the records or position they occupy in the National, European, World or Olympic Championships. Therefore, each athlete of this study has participated at least in the final contest of the corresponding Spanish Championship. The athletes included in this list obtain a fellowship and have the possibility of accessing to the Sportsmen Service of the Generalitat Valenciana where they receive training, medical and nutritional support. Ergometry and anthropometry probes are freely provided by this service. The anthropometric measurements performed in this large population constitute the basis of this reference list.

The following skinfolds were measured: triceps $(\mathrm{T})$, subscapular (Sb), suprailiac (Sp), abdominal (A), thigh calf (TC) and medial calf (MC). Skinfold calliper (Holtain, UK) was used and calibrated according to the manufacturers' instructions. Anthropometric measurements were performed according to ISAK standards (Marfell-Jones et al.). Two experienced persons performed independently each determination twice, considering valid values when standard deviation of each measurement was lower than $7 \%$ (Marfell-Jones et al.). The following sums were considered for fat content calculations: six skinfolds (SSS= $\mathrm{T}+\mathrm{Sb}+\mathrm{Sp}+\mathrm{A}+\mathrm{TC}+\mathrm{MC}$ ), upper body skinfolds (SUBS= $\mathrm{T}+\mathrm{Sb})$, trunk skinfolds $(\mathrm{STS}=\mathrm{Sp}+\mathrm{A})$ and lower body skinfolds (SLBS $=\mathrm{TC}+\mathrm{MC}$ ). Fat weight and percentage were calculated using Yuhasz equation modified by Faulkner (1968). Bone mass and percentage were calculated according to Rocha (Marfell-Jones et al.). Muscle mass and percentage were calculated from Martin's equation (Martin et al., 2003).

Descriptive statistics presents data as mean \pm standard deviation (SD) and percentile values at $95 \%$ confidence interval. SPSS 11.1 for Windows was used.

\section{RESULTS}

We performed anthropometric determinations in 2500 top level athletes, 1771 males (70.8\%) and 729 females $(29.2 \%)$. The mean age \pm SD of the studied population was $21.3 \pm 6.1$ years, $22.5 \pm 6.4 \mathrm{in}$ men and $18.5 \pm 4.0$ in women. The mean weight \pm SD of the studied population was $70.8 \pm 14.8$ $\mathrm{kg}, 75.5 \pm 13.8 \mathrm{~kg}$ for men and $59.4 \pm 10.3 \mathrm{~kg}$ for women. The mean height $\pm S D$ was $175.2 \pm 11.5 \mathrm{~cm}, 179.2 \pm 10.2 \mathrm{~cm}$ for men and $165.6 \pm 8.5 \mathrm{~cm}$ for women. The mean $\%$ of fat mass \pm SD was $12.7 \pm 3.1 \%, 12.2 \pm 2.8 \%$ for men and $14.1 \pm 3.2 \%$ for women. The mean $\%$ of bone mass \pm SD was $17.1 \pm 2.1 \%$, $17.2 \pm 2.0 \%$ for men and $16.9 \pm 2.3 \%$ for women. The mean $\%$ of muscle mass was $43.0 \pm 10.6 \%, 46.8 \pm 9.5 \%$ for men and $33.7 \pm 6.6 \%$ for women. The sport disciplines practiced by the athletes are shown in Table VA and VB.

Table I presents the means \pm SD of the different skinfolds in the whole population, men and women. The mean highest values can be observed for TC and A skinfolds, meanwhile the lowest value corresponded to Sb. Female athletes displayed higher skinfold values than men. Classification in 3 percentiles $\left(10^{\text {th }}, 50^{\text {th }}\right.$ and $\left.90^{\text {th }}\right)$ was performed for the whole population (Table IIA), men (Table IIB) and women (Table IIC). In the whole population, at 50th percentile, the athletes could be classified into two groups depending on their skinfold values: those which values were close to $8 \mathrm{~mm}(\mathrm{~T}, \mathrm{Sb}, \mathrm{Sp}$ and $\mathrm{MC})$ and the rest which were approximately at $12 \mathrm{~mm}$ (A and TC). At the 10th percentile, all skinfolds were comprised in a narrow interval $(3.8-5.7 \mathrm{~mm})$. At $90^{\text {th }}$ percentile, two groups were 
also observed: one at approximately $14-17 \mathrm{~mm}(\mathrm{~T}, \mathrm{Sb}$ and MC) and another at 20-25 mm (Sp, A and TC). In men, a similar pattern was seen at $50^{\text {th }}$ percentile. At 10 th percentile, all male skinfolds displayed higher values than those in the whole population, ranging from $4.6-7.0 \mathrm{~mm}$. At $90^{\text {th }}$ percentile, the same groups as in the whole population could be observed again, one comprising T, Sb and MC skinfolds (around $13.5 \mathrm{~mm}$ ), and another using $\mathrm{Sp}$, A and TC skinfolds (18.0-25.0 mm). At 50 th percentile, women's T, Sp, A and MC skinfolds ranged between 12.0-15.4 mm, and $\mathrm{Sb}$ and TC displayed the lowest and highest values respectively. In addition, women displayed the highest values of skinfolds at $10^{\text {th }}$ and $90^{\text {th }}$ percentiles compared to men.
Table I. Mean \pm SD values of skinfolds in $\mathrm{mm}$ of the studied population.

\begin{tabular}{ccrc}
\hline Skinfold & Whole population & Men & Women \\
\hline T & $9.4 \pm 5.2$ & $8.6 \pm 3.3$ & $14.1 \pm 4.6$ \\
Sb & $8.9 \pm 4.6$ & $9.5 \pm 3.6$ & $10.2 \pm 4.1$ \\
Sp & $10.2 \pm 6.9$ & $10.1 \pm 6.0$ & $13.5 \pm 6.7$ \\
A & $13.0 \pm 8.3$ & $13.2 \pm 7.4$ & $16.6 \pm 7.5$ \\
TC & $14.2 \pm 8.2$ & $12.6 \pm 5.4$ & $22.3 \pm 6.7$ \\
MC & $9.3 \pm 5.8$ & $8.4 \pm 4.0$ & $14.2 \pm 5.4$ \\
\hline
\end{tabular}

Table II. Skinfolds classified in percentiles.

A) Skinfolds in mm classified by percentiles in the whole population.

\begin{tabular}{ccccccc}
\hline Percentile & T & Sb & Sp & A & TC & MC \\
\hline $\mathbf{1 0} \mathbf{t}^{\mathbf{h}}$ & 4.3 & 5.3 & 4.0 & 5.1 & 5.7 & 3.8 \\
$\mathbf{5 0} \mathbf{t}^{\mathbf{h}}$ & 8.8 & 8.5 & 8.6 & 11.35 & 12.6 & 8.2 \\
$\mathbf{9 0} \mathrm{t}^{\mathbf{h}}$ & 16.2 & 14.0 & 20.0 & 25.2 & 25.5 & 16.9 \\
\hline
\end{tabular}

B) Skinfolds in mm classified by percentiles in male athletes.

\begin{tabular}{ccccccc}
\hline Percentile & T & Sb & Sp & A & TC & MC \\
\hline $\mathbf{1 0} \mathbf{t}^{\mathbf{h}}$ & 5.2 & 6.6 & 5.2 & 6.4 & 7.0 & 4.6 \\
$\mathbf{5 0} \mathbf{t}^{\mathbf{h}}$ & 8.0 & 8.6 & 8.2 & 10.8 & 11.4 & 7.4 \\
$\mathbf{9 0} \mathbf{t}^{\mathbf{h}}$ & 13.0 & 13.9 & 18.0 & 25.0 & 20.1 & 13.4 \\
\hline
\end{tabular}

C) Skinfolds in mm classified by percentiles in female athletes.

\begin{tabular}{ccccccc}
\hline Percentile & T & Sb & Sp & A & TC & MC \\
\hline $\mathbf{1 0} \mathbf{t}^{\mathbf{h}}$ & 8.8 & 6.2 & 6.0 & 7.8 & 13.4 & 8.2 \\
$\mathbf{5 0} \mathbf{t}^{\mathbf{h}}$ & 13.5 & 9.2 & 12.0 & 15.4 & 22.0 & 13.2 \\
$\mathbf{9 0} \mathrm{t}^{\mathbf{h}}$ & 20.3 & 16.2 & 23.4 & 28.0 & 31.5 & 22.0 \\
\hline
\end{tabular}

Table III. Mean \pm SD values of skinfold sums in $\mathrm{mm}$ in the studied population.

\begin{tabular}{lcll}
\hline \multicolumn{1}{c}{ Skinfold sums } & Whole Population & \multicolumn{1}{c}{ Men } & Women \\
\hline $\boldsymbol{\Sigma}$ SS & $64.9 \pm 35.1$ & $62.6 \pm 25.6$ & $91.1 \pm 31.1$ \\
$\boldsymbol{\Sigma}$ UBS & $18.3 \pm 9.0$ & $18.2 \pm 6.2$ & $24.4 \pm 8.1$ \\
$\boldsymbol{\Sigma}$ TS & $23.2 \pm 14.6$ & $23.4 \pm 12.7$ & $30.1 \pm 13.6$ \\
$\boldsymbol{\Sigma} \mathbf{L B S}$ & $23.4 \pm 13.5$ & $21.0 \pm 8.8$ & $36.6 \pm 11.3$ \\
\hline
\end{tabular}

As complementary information about the local body fat distribution in our studied population, we present the skinfold sums by body segments (Table III). To this end, we divided the body in 3 parts: upper body, trunk and lower body, and two skinfolds were measured in each part: $\mathrm{T}$ and $\mathrm{Sb}$ in upper body, Sp and A in trunk, and TC and MC in lower body. The trunk and lower body presented the highest values, indicating a preferential distribution of fat in these 
Table IV. Skinfold sums in mm classified by percentiles.

A) Skinfold sums in mm classified by percentiles in the whole population.

\begin{tabular}{ccccc}
\hline Percentile & $\boldsymbol{\Sigma} S \mathbf{S S}$ & $\boldsymbol{\Sigma}$ UBS & $\boldsymbol{\Sigma}$ TS & $\boldsymbol{\Sigma} \mathbf{L B S}$ \\
\hline $\mathbf{1 0} \mathbf{t}^{\mathbf{h}}$ & 32.8 & 10.6 & 9.7 & 10.2 \\
$\mathbf{5 0} \mathbf{t}^{\mathbf{h}}$ & 59.7 & 17.6 & 20.5 & 21.0 \\
$\mathbf{9 0} \mathbf{t}^{\mathbf{h}}$ & 111.9 & 29.4 & 44.2 & 41.3 \\
\hline
\end{tabular}

B) Skinfold sums in mm classified by percentiles in male athletes.

\begin{tabular}{ccccc}
\hline Percentile & $\boldsymbol{\Sigma S S}$ & $\boldsymbol{\Sigma}$ UBS & $\boldsymbol{\Sigma T S}$ & $\boldsymbol{\Sigma} \mathbf{L B S}$ \\
\hline $\mathbf{1 0} \boldsymbol{t}^{\mathbf{h}}$ & 38.2 & 12.4 & 12.0 & 12.2 \\
$\mathbf{5 0} \boldsymbol{t}^{\mathbf{h}}$ & 55.2 & 16.9 & 19.2 & 18.8 \\
$\mathbf{9 0}^{\mathbf{h}}$ & 97.1 & 26.0 & 41.6 & 33.0 \\
\hline
\end{tabular}

C) Skinfold sums in mm classified by percentiles in female athletes.

\begin{tabular}{ccccc}
\hline Percentile & $\boldsymbol{\Sigma S S}$ & $\boldsymbol{\Sigma U B S}$ & $\boldsymbol{\Sigma T S}$ & $\boldsymbol{\Sigma} \mathbf{L B S}$ \\
\hline $\mathbf{1 0}^{\mathbf{h}}$ & 54.1 & 15.2 & 13.5 & 22.6 \\
$\mathbf{5 0}^{\mathbf{h}}$ & 86.6 & 23.0 & 27.8 & 35.5 \\
$\mathbf{9 0}^{\mathbf{h}}$ & 135.7 & 35.4 & 51.0 & 53.6 \\
\hline
\end{tabular}

Table VA. Sport disciplines, $\%$ fat and skinfold sums in men. Values are expressed as means \pm SD

\begin{tabular}{|c|c|c|c|c|c|c|}
\hline Sport discipline & Number of Athletes & \% Fat & $\Sigma S S$ & $\Sigma$ UUBS & $\Sigma T S$ & $\Sigma$ LBBS \\
\hline Alpinism & 35 & $11.1 \pm 2.0$ & $53.1 \pm 21.7$ & $16.7 \pm 7.4$ & $18.1 \pm 7.8$ & $18.3 \pm 10.3$ \\
\hline Athletics & 99 & $11.4 \pm 3.5$ & $56.9 \pm 35.2$ & $16.4 \pm 8.5$ & $20.3 \pm 4.9$ & $20.1 \pm 12.8$ \\
\hline Badminton & 89 & $11.3 \pm 1.6$ & $56.3 \pm 14.6$ & $16.7 \pm 3.4$ & $19.5 \pm 7.4$ & $20.1 \pm 5.2$ \\
\hline Basketball & 275 & $12.8 \pm 3.0$ & $69.5 \pm 27.2$ & $19.5 \pm 6.9$ & $26.2 \pm 13.6$ & $23.8 \pm 9.1$ \\
\hline Basque pelota & 2 & $12.5 \pm 0.6$ & $66.1 \pm 4.7$ & $16.8 \pm 1.2$ & $27.1 \pm 2.5$ & $22.3 \pm 1.0$ \\
\hline Cycling & 18 & $11.7 \pm 2.4$ & $60.5 \pm 23.2$ & $17.5 \pm 5.3$ & $21.3 \pm 10.6$ & $21.7 \pm 9.0$ \\
\hline Frontenis & 26 & $13.4 \pm 2.7$ & $79.3 \pm 26.7$ & $22.4 \pm 7.0$ & $27.4 \pm 12.0$ & $29.5 \pm 10.7$ \\
\hline Golf & 1 & 10.9 & 52.2 & 16.8 & 16.6 & 18.8 \\
\hline Gymnastics & 18 & $9.6 \pm 0.5$ & $39.9 \pm 8.0$ & $13.2 \pm 1.4$ & $11.9 \pm 1.9$ & $14.7 \pm 6.0$ \\
\hline Hockey & 13 & $15.1 \pm 4.9$ & $91.7 \pm 45.8$ & $25.6 \pm 11.6$ & $35.0 \pm 20.5$ & $31.1 \pm 15.8$ \\
\hline Handball & 110 & $14.1 \pm 3.1$ & $77.2 \pm 27.5$ & $20.4 \pm 6.6$ & $33.9 \pm 14.6$ & $23.0 \pm 8.6$ \\
\hline Indoor soccer & 129 & $15.1 \pm 3.1$ & $87.1 \pm 27.7$ & $23.9 \pm 7.1$ & $37.0 \pm 13.9$ & $26.2 \pm 10.0$ \\
\hline Judo & 19 & $11.7 \pm 4.4$ & $58.7 \pm 38.3$ & $18.4 \pm 10.8$ & $20.4 \pm 18.0$ & $19.9 \pm 10.5$ \\
\hline Motornautics & 1 & 11.5 & 58.3 & 17.3 & 20.1 & 20.9 \\
\hline Orienteering & 59 & $10.8 \pm 1.3$ & $52.0 \pm 13.9$ & $15.8 \pm 3.9$ & $16.6 \pm 5.3$ & $19.6 \pm 6.7$ \\
\hline Rowing & 65 & $14.0 \pm 3.2$ & $81.6 \pm 29.3$ & $21.8 \pm 5.6$ & $31.7 \pm 16.1$ & $28.0 \pm 9.2$ \\
\hline Rugby & 2 & $13.1 \pm 2.4$ & $74.8 \pm 28.8$ & $20.1 \pm 5.2$ & $28.0 \pm 10.2$ & $26.7 \pm 13.4$ \\
\hline Sailing & 1 & 11.7 & 54.2 & 16.3 & 22.4 & 15.5 \\
\hline Scuba diving & 7 & $16.1 \pm 4.6$ & $98.4 \pm 39.7$ & $25.9 \pm 9.8$ & $41.4 \pm 21.7$ & $31.0 \pm 10.9$ \\
\hline Soccer & 643 & $11.3 \pm 1.6$ & $53.7 \pm 15.2$ & $16.6 \pm 3.8$ & $19.2 \pm 7.3$ & $17.9 \pm 6.4$ \\
\hline Squash & 1 & 9.0 & 31.0 & 10.7 & 10.4 & 9.9 \\
\hline Swimming & 30 & $11.0 \pm 1.9$ & $54.9 \pm 16.2$ & $16.4 \pm 4.8$ & $17.4 \pm 7.8$ & $21.1 \pm 4.8$ \\
\hline Table tennis & 21 & $14.6 \pm 3.6$ & $86.0 \pm 25.9$ & $23.1 \pm 7.6$ & $34.5 \pm 16.7$ & $28.4 \pm 7.2$ \\
\hline Tennis & 31 & $12.5 \pm 2.6$ & $69.7 \pm 23.7$ & $19.8 \pm 5.7$ & $24.2 \pm 11.8$ & $25.7 \pm 8.2$ \\
\hline Triathlon & 40 & $11.0 \pm 1.7$ & $49.9 \pm 15.7$ & $15.2 \pm 3.2$ & $18.8 \pm 8.2$ & $16.0 \pm 5.3$ \\
\hline Volleyball & 36 & $10.9 \pm 1.3$ & $50.9 \pm 12.8$ & $15.2 \pm 4.0$ & $18.0 \pm 5.1$ & $17.7 \pm 5.0$ \\
\hline
\end{tabular}


GARRIDO-CHAMORRO, R.; SIRVENT-BELANDO, J. E.; GONZÁLEZ-LORENZO, M.; BLASCO-LAFARGA, C. \& ROCHE, E. Skinfold sum: reference values for top athletes. Int. J. Morphol., 30(3):803-809, 2012.

Table VB. Sport disciplines, \% fat and skinfold sums in women. Values are expressed as means \pm SD

\begin{tabular}{lcccccc}
\hline Sport discipline & $\begin{array}{c}\text { Number of } \\
\text { athletes }\end{array}$ & \%Fat & $\boldsymbol{\Sigma S S}$ & $\boldsymbol{\Sigma}$ UBS & $\boldsymbol{\Sigma}$ TS & $\boldsymbol{\Sigma}$ LBS \\
\hline Alpinism & 7 & $13.0 \pm 1.1$ & $79.0 \pm 11.1$ & $22.7 \pm 3.1$ & $24.3 \pm 4.3$ & $31.9 \pm 6.1$ \\
Athletics & 89 & $14.6 \pm 3.8$ & $94.8 \pm 36.7$ & $26.3 \pm 10.2$ & $31.5 \pm 15.5$ & $37.0 \pm 12.4$ \\
Badminton & 66 & $14.3 \pm 1.7$ & $93.9 \pm 16.6$ & $24.7 \pm 4.3$ & $31.1 \pm 7.4$ & $38.1 \pm 7.3$ \\
Basketball & 137 & $16.0 \pm 3.4$ & $110.6 \pm 31.9$ & $29.5 \pm 9.1$ & $37.3 \pm 14.0$ & $43.8 \pm 11.0$ \\
Cycling & 1 & 13.2 & 82.8 & 21.8 & 26.7 & 34.3 \\
Frontenis & 5 & $14.5 \pm 2.8$ & $98.3 \pm 31.7$ & $25.8 \pm 7.4$ & $31.2 \pm 12.4$ & $41.4 \pm 16.4$ \\
Hockey & 4 & $13.4 \pm 5.0$ & $78.9 \pm 40.2$ & $22.4 \pm 12.7$ & $27.4 \pm 20.4$ & $29.1 \pm 9.1$ \\
Handball & 15 & $16.7 \pm 3.6$ & $113.0 \pm 32.0$ & $32.0 \pm 8,6$ & $39.2 \pm 15.9$ & $41.8 \pm 9.0$ \\
Indoor soccer & 16 & $13.0 \pm 2.1$ & $79.2 \pm 19.4$ & $23.3 \pm 4.0$ & $23.9 \pm 11.2$ & $32.1 \pm 8.5$ \\
Judo & 39 & $12.7 \pm 2.1$ & $77.1 \pm 17.3$ & $22.0 \pm 4.3$ & $23.2 \pm 10.3$ & $31.9 \pm 6.9$ \\
Orienteering & 30 & $14.1 \pm 1.6$ & $91.2 \pm 15.1$ & $22.6 \pm 3.8$ & $31.5 \pm 7.8$ & $37.1 \pm 6.7$ \\
Rhythmic ymnastics & 76 & $10.2 \pm 1.2$ & $50.2 \pm 13.2$ & $14.7 \pm 2.9$ & $14.0 \pm 5.4$ & $21.5 \pm 5.9$ \\
Rowing & 21 & $15.6 \pm 1.9$ & $100.5 \pm 16.5$ & $26.0 \pm 6.2$ & $38.0 \pm 9.5$ & $36.4 \pm 7.2$ \\
Sailing & 2 & $16,34 \pm 0.7$ & $117.6 \pm 8.0$ & $33.6 \pm 1.5$ & $35.5 \pm 5.9$ & $48.6 \pm 3.6$ \\
Skating & 1 & 14.1 & 95.9 & 27.0 & 27.5 & 41.4 \\
Soccer & 106 & $14.9 \pm 2.9$ & $100.0 \pm 8.5$ & $25.6 \pm 7.0$ & $34.1 \pm 12.7$ & $40.3 \pm 11.0$ \\
Swimming & 59 & $13.0 \pm 2.8$ & $80.3 \pm 25.4$ & $21.5 \pm 6.6$ & $25.4 \pm 11.8$ & $33.4 \pm 9.8$ \\
Tennis & 31 & $14.2 \pm 2.1$ & $92.0 \pm 19.9$ & $22.5 \pm 5.6$ & $32.4 \pm 9.2$ & $37.1 \pm 7.1$ \\
Triathlon & 6 & $11.5 \pm 1.2$ & $72.8 \pm 13.7$ & $20.7 \pm 4.2$ & $16.9 \pm 3.8$ & $35.2 \pm 6.3$ \\
Volleyball & 18 & $14.3 \pm 2.2$ & $93.2 \pm 17.9$ & $25.6 \pm 5.8$ & $30.3 \pm 9.8$ & $37.4 \pm 8.4$ \\
\hline
\end{tabular}

body segments in the whole population. Comparing lower body and trunk, it seems that fat content tends to be slightly higher in the lower body. This pattern was also seen in the female athletes, whereas in men the trunk values were higher than in lower body. According to Table IVA, this pattern was observed, as expected, at the $50^{\text {th }}$ percentile in the whole population. At $90^{\text {th }}$ percentile, the same pattern was seen, but the sum of trunk skinfolds predominated. At $10^{\text {th }}$ percentile, the sums of the different body parts tend to display the similar-most values. In men, the sums of skinfolds in the different body segments tend to display uniform values at $10^{\text {th }}$ and $50^{\text {th }}$ percentiles (Table IVB). At $90^{\text {th }}$ percentile, trunk and lower body parts also displayed higher values compared to the upper body, being the trunk the category with the highest values. In women, the lower body segment displayed the highest skinfold values at $10^{\text {th }}$ and $50^{\text {th }}$ percentile (Table IVC). This tendency was not maintained at $90^{\text {th }}$ percentile, where trunk skinfold sum tend to be closest to lower body skinfold sum.

Finally, Tables VA and VB present the percentage of fat and skinfold sums in the different sport disciplines, both in men (Table VA) and women (Table VB). Individuals practicing disciplines such as hockey, handball, indoor soccer, rowing, scuba diving and table tennis had the highest fat percentages and thereby the highest values for SSS. In all cases and according to partial sums, the major fat deposition seemed to be located at the trunk in men. On the other hand, the lowest fat content could be observed in individuals practicing gymnastics and orienteering. In these cases and according to partial sum values, fat deposition seemed to be predominant in the lower body part.

In the case of women, they generally displayed higher fat percentages than men for each particular discipline. Few exceptions can be mentioned, such as hockey and indoor soccer, but the $\mathrm{n}$ values were very different and thereby it is difficult to compare both disciplines in order to reach a conclusion. The higher fat percentages were found in basketball, handball and sailing athletes. As opposed to male athletes, in these cases the partial sums indicated that the lower body is a predominant location for fat deposition in women. This pattern could be observed as well in women with the lowest fat percentages, which consisted in those practicing judo, rhythmic gymnastics and triathlon. 


\section{DISCUSSION}

Skinfold sum is an acceptable parameter to estimate fat component in athletes. This can be performed directly by coaches or medical staff, providing key data for seasonal planning (Malina). One of the limitations of this method is the absence of reference lists that can be useful to more precisely evaluate fat contents for particular sport disciplines. The objective of this work has been the recompilation of these data in a large population of athletes reported so far.

Newer technology, such as dual-energy X-ray absorptiometry (DXA), magnetic resonance (MR) and computerized tomography $(\mathrm{CT})$ are more reliable than anthropometry. For this reason, the use of prediction equations to calculate fat content could be questioned, but the literature shows that equations have an estimated standard error of 3-7\% and body fat content calculations are very similar to those obtained using the most precise technology (Wang et al.; Reilly et al., 2009). In addition DXA, MR and CT are very expensive and only available to a few research centres. On the other hand, anthropometry has a strong potential in estimating body fat, since it is available to most sport researchers, medical staff, nutritionists and trainers.

An interesting tool indicated in this study is the use of partial skinfold sums at different body segments. Local sums allows the analysis of fat content in different anatomical areas in the same individual, but at the same time to compare fat distribution according to different sport disciplines. Skinfold sum has a direct correlation with fat content and thus, the thickness of skinfolds in certain body segments is directly related to local fat accumulation. In addition, the selected skinfolds (T, Sb, Sp, A, TC and MC) were the most frequently used measurements in the 50 commonly-most prediction equations used to estimate body fat content (Wang et al.). In this context, fatty mass calculation in athletes should consider the six skinfold sum instead of the four (T, Sb, Sp and A) that are used in other prediction equations (Marfell-Jones et al.). We also observed that body fat tends to be localized in the trunk and lower body segments in athletes. Other equations use additional skinfolds to calculate body fat, usually bicipital and pectoral skinfolds (there are more than 19 skinfold sites) (Marfell-Jones et al.; Wang et al.; van der Ploeg et al., 2003). The addition of these skinfolds could improve the precision of the total fat value, however the majority of the measurements are taken from the upper body area, an area where athletes do not seem to accumulate fat. Altogether, we consider as more appropriate for athletes the use of prediction equations that include the sum of six skinfolds to calculate body fat content (Marfell-Jones et al.). Moreover, fat tends to be localized in the trunk and lower body segments and varies according to gender and discipline.

\section{ACKNOWLEDGMENTS}

We want to thank all the colleagues from the Centro de Tecnificación de Alicante for their technical help.

GARRIDO-CHAMORRO, R.; SIRVENT-BELANDO, J. E.; GONZÁLEZ-LORENZO, M.; BLASCO-LAFARGA, C. \& ROCHE, E. Sumatorio de pliegues subcutáneos: valores de referencia para atletas de élite. Int. J. Morphol., 30(3):803-809, 2012.

RESUMEN: Las determinaciones de los pliegues subcutáneos de diferentes zonas corporales son utilizadas ocasionalmente en ecuaciones predictivas para calcular la masa grasa. Éste es un parámetro crítico que condiciona el óptimo rendimiento deportivo. No existen valores de referencia de pliegues subcutáneos en atletas de élite. Por tanto, el principal objetivo de este estudio es presentar valores de referencia de pliegues subcutáneos de una amplia población de atletas. Los pliegues tricipital, subescapular, suprailiaco, abdominal, muslo y pierna fueron medidos de acuerdo a la normativa ISAK (Sociedad Internacional para el Avance de la Cineantropometría) en 2500 atletas. La suma de los seis pliegues así como las sumas parciales de diferentes segmentos corporales (superior, troncal e inferior) fueron calculadas. Los datos muestran que los valores más altos de pliegues subcutáneos fueron observados en el muslo y zona abdominal, siendo el pliegue subescapular el menor. Las mujeres presentaron valores más altos de pliegues subcutáneos que los hombres. Respecto a las sumas parciales, los segmentos corporales troncal e inferior presentaron las mayores puntuaciones. Los practicantes de hockey, balonmano, fútbol sala, remo, submarinismo y tenis de mesa mostraron los mayores porcentajes de grasa. En conclusión, los cálculos de masa grasa en atletas deberían de considerar el sumatorio de los seis pliegues subcutáneos. Además, la grasa corporal tiende a estar localizada en los segmentos corporales troncal e inferior y varía según el género y la disciplina deportiva.

PALABRAS CLAVE: Antropometría; Grasa corporal; Pliegues subcutáneos; Segmentos corporales; Deportes. 
GARRIDO-CHAMORRO, R.; SIRVENT-BELANDO, J. E.; GONZÁLEZ-LORENZO, M.; BLASCO-LAFARGA, C. \& ROCHE, E. Skinfold sum: reference values for top athletes. Int. J. Morphol., 30(3):803-809, 2012.

\section{REFERENCES}

Deurenberg, P.; van der Kooy, K.; Hulshof, T. \& Evers, P. Body mass index as a measure of body fatness in the elderly. Eur. $J$. Clin. Nutr., 43(4):231-6, 1989.

Faulkner, J. A. Physiology of swimming and diving. In: Falls, H. (Ed.). Exercise Physiology. Baltimore, Academic Press, 1968.

Kagawa, M.; Kerr, D.; Uchida, H. \& Binns, C. W. Differences in the relationship between BMI and percentage body fat between Japanese and Australian-Caucasian young men. Br. J. Nutr., 95(5):1002-7, 2006.

Malina, R. M. Body composition in athletes: assessment and estimated fatness. Clin. Sports Med., 26(1):37-68, 2007.

Marfell-Jones, M.; Olds, T., Stewart, A. \& Carter, L. International standards for anthropometric assessment. Potchefstroom, South Africa, ISAK, 2006.

Martin, A. D.; Daniel, M.; Clarys, J. P. \& Marfell-Jones, M. J. Cadaver-assessed validity of anthropometric indicators of adipose tissue distribution. Int. J. Obes. Relat. Metab. Disord., 27(9):1052-8, 2003.

Reilly, T.; George, K.; Marfell-Jones, M.; Scott, M.; Sutton, L. \& Wallace, J. A. How well do skinfold equations predict percent body fat in elite soccer players? Int. J. Sports Med., 30(8):607$13,2009$.

van der Ploeg, G. E.; Gunn, S. M.; Withers, R. T. \& Modra, A. C. Use of anthropometric variables to predict relative body fat determined by a four-compartment body composition model. Eur. J. Clin. Nutr., 57(8):1009-16, 2003.

Wang, J.; Thornton, J. C.; Kolesnik, S. \& Pierson, Jr. N. Anthropometry in body composition. An overview. Ann. N.Y. Acad. Sci., 904:317-26, 2000.

WHO Expert Consultation. Appropriate body mass index for Asian populations and its implications for policy and intervention strategies. Lancet, 363(9403):157-63, 2004.
Correspondence to:

Dr. Enrique Roche

Department of Applied Biology-Nutrition

University Miguel Hernandez of Elche

Alicante

SPAIN

\section{Email: eroche@umh.es}

Received: 18-01-2012

Accepted: 05-06-2012 